\title{
Invigorating foreign aid administration: remittances' strategy, pro-poor and gender focus
}

Adebayo Adedokun

\author{
Correspondence: dokbayo@gmail. \\ com \\ Department of Economics, Obafemi \\ Awolowo University, lle-Ife, Nigeria
}

\begin{abstract}
Background: The pitfall of top-down approach to development is identified as a major cause of aid inefficiency. The approach is fraught with corruption and unethical practices that have bedeviled aid administration. Meanwhile, the impact of remittances has been widely acknowledged in the national development process.

Methods: This study therefore reviews the extant foreign aid administrative norms and practices using various conceptual frameworks and diagrammatic representations with a view to identifying the inherent weaknesses in the process.
\end{abstract}

Results: In the light of the findings, the study pitches its tent around the concept of remittances as a learning process for aid administration. Consequently, the pro-poor and gender focus approaches of remittances to development, as well as its bottomup approach is proposed as a conceptual framework for aid administration.

Conclusions: The study concludes that, strict adherence to bottom-up approaches proposed in this article would keep corruption and other unethical practices which have rendered the aid administrative process inefficient, to the barest minimum.

Keywords: Foreign Aid; Remittances; Pro-Poor Aid; Gender Focus Aid

\section{Springer}

\section{Background}

Aid has become a formal institution created to implement development action aimed at improving global equity, (McMichael 2011). Conceptually, aid involves the transfer of resources from materially wealthy countries to materially poor countries, (Kaplan 1999). However, as evaluations of aid administration and effectiveness are carried out over time, the definition is reframed to align with the current reality of the administrative procedure. Thus, the current and revolutionary perspective of aid is aligned with the concept of sustainable development (Morrissey 2002; Asongu 2015). Foreign aid by structure is usually committed into the hands of an organization that operates as intermediary between the donors and beneficiaries. In other words, agencies are responsible for the administration of the process, while progress and evaluative reports are given in return to the original aid donors.

The argument around the agencies control process was borne out of the search for aid efficiency and effectiveness. The notion is that agencies in receiving country would understand the reality around the needs and administration of the process more than the donors who are mostly based in the developed economies. However, in many

(C) 2015 Adedokun. Open Access This article is distributed under the terms of the Creative Commons Attribution 4.0 International License (http://creativecommons.org/licenses/by/4.0/), which permits unrestricted use, distribution, and reproduction in any medium, provided you give appropriate credit to the original author(s) and the source, provide a link to the Creative Commons license, and indicate if changes were made. 
literatures and as emphasised in this article, the factors inhibiting aid efficiency, effectiveness and sustainability are not far from the confinement of aid administration on semi-independent agencies serving as intermediary in the recipient countries. In principle the argument of Sachs in 'the on ending poverty' is valid, when he highlighted the process to ending poverty through careful deployment of development aid, provided that the inefficiencies are adequately corrected (Sachs 2006).

The sustainability of aid outcome which is critical to the current definition is somehow controversial, thus it is necessary to clarify issues around the sustainable and unsustainable aid (Crawford 2004) gave a brief clarification when it is stated that, 'the effectiveness of aid in fostering sustainable development is at least partly contingent on the performance of the implementing agency. The performance of an aid agency is in turn contingent on a complex interaction of factors that include organizational culture, personnel competencies, leadership behaviors and management system'.

This article 'invigorating foreign aid administration', takes a close look at the relative effectiveness of remittances administration which aims relatively the same target as does the foreign aid, but with more effective impact than foreign aid. Comparatively, both of them aim at fostering development in the recipient countries, however, they are applied through different media and they target different audience as development transmission agents. For instance, remittances are directed at the households as the main agents of development, while, foreign aid is routed through government and non-governmental channels to address development challenges in recipient countries. The ultimate target of foreign aid is to alleviate poverty in all its ramifications. By implication, it seeks to harness all available channels, including private investment, households, and government as the overriding platform to achieve the developmental goals. Obviously, remittances is a different concept from aid, but its relevance in this discourse could not be overemphasized, given the indirect comparison that could enhance the effectiveness of the latter.

This article is structured as follows; next section identifies and discusses some of the contending issues around the current approach to administration of foreign aid. The discussion is supported with a simple conceptual frame of current aid structure. It thereafter discusses the concept of remittances and its administrative structure that could assist in actualizing the target of aid donors. It is followed with a conceptual frame of remittances administration to elucidate the learning point for invigorating aid administration. The proposal for new procedure is then presented using simple conceptual frame and the paper is concluded.

\section{Foreign aid and contending issues Moral hazard argument}

Three motives are identified for the advancement of aid; the relative importance of recipients' need, recipient's merit and self-interest of donors (Nunnenkamp \& Öhler 2011). However, the needs of recipients dominate the reasons for multilateral aid. This is in line with an argument by (Easterly 2002), that, indebted countries persistently remain indebted as a strategy to establish a need base for donors' continual aid support. The argument is the fundamental basis for moral hazard in foreign aid administration.

The moral hazard argument emerges especially from generational debate of bad fund management in Africa. It claims that the large inflows of foreign aid to Africa since 60s has worsened economic and human development in the continent, by empowering selfish 
elites, who occupied leadership seats. It further argues that aid and foreign loans encounter poor accountability and repayment problem, as a result of visionless leaders with little or no interest in sustainable development (Bulow \& Rogoff 1991; Moyo 2009).

\section{Weak and corrupt administrative agents argument}

Aid administration is structured with lots of factors that are capable of rendering it ineffective. The donors' interest usually differs from those of administrative agencies who are either NGOs or government agencies in the recipient country. In the current structure of foreign aid administration, the implementing agencies take vital decisions on aid which reflect their selfish interest either to influence political perpetuation and survival of the ruling government or as a guiding tool to fortify their individual socioeconomic status at the expense of the original target of aid. (Bodomo 2013) stated that 'leaders make aid and policy decisions with an eye on how they influence political survival'. The self-aggrandizement of 'the middlemen' in the process limits the ability to have a focused aid administration, and thereby rendering the process ineffective.

Foreign aid misappropriation is paramount at all levels, (Moyo 2009). The magnitude of official corruption that is attributed to aid management is endemic (Bodomo 2013) argued that in some cases less than $10 \%$ of aid benefit the most vulnerable group, the remaining $90 \%$ end up in the pocket of officials of government and non-governmental organisations and even the foreign aid workers who are actually being paid huge sums to make them princes and princesses in the midst of poverty they were trained to eradicate. Unfortunately, a corrupt genius is quick to tighten up all loopholes and decorate an empty box as a treasure tank. This is one of the attributes of many NGOs and government agencies that are saddled with the responsibility to administer aid. In a broader sense, the quest for selfenrichment and political survival motivate, to some extent, the quantity and quality of activities performed within the original document of the aid contracts. The implementers are not unaware that donors expect progress report, but many of the agencies have garnered several years of experience in the operations and are not wary of the content and the languages the donor expect in the reporting document. To this effect, in the absence of any implementation, many agencies could produce detailed and adequate upfront report of projects before execution. Unfortunately, donors place high priority on the progress report than the actual and the real life output and outcome of the fund expended on a project.

Recently, the limitations of complete dependence on agencies' documented report of project outcome came to limelight in the case of Haiti. A number of NGOs and government agencies were saddled with aid administration responsibilities in Haiti after the earthquake in 2010. Two years after, the Haiti crisis persisted, despite huge sum of more than 12 billion dollars expended in form of humanitarian aid. This development raised big questions on the reliability of the NGOs and government agencies that were responsible for the post-earthquake aid administration. As Cunningham puts it, 'despite the efforts of the United Nations Stabilisation Mission in Haiti (MINUSTAH), International Organization (IOs), Non-Governmental Organisations (NGOs), and Private Volunteer Organization (PVOs), Haiti remains in critical condition two years later, begging the question: where did the money go?' (Ghani et al. 2005)

Only three concepts are relevant to answering Cunningham's question, it could either be 'incompetence,' 'inefficiency' or 'corruption'. These are briefly justified;

Poor coordination and harmonization among the agencies (NGOs): inefficiency is inherent in the aid contract at the inception. Usually, many implementing agencies target 
the same problems within the same communities at the same or closely related time. The failure to take inventory of completed projects or ongoing projects or pipeline projects usually leads to duplication of efforts and consequently wastage and inefficiency. Poor coordination is a regular occurrence when multiple agencies offer aid to solve the same problem. The entire work of (Banerjee \& He 2007) in the article, 'Making Aid Work' centers on poor coordination of agencies during the emergent response to the Pakistan's earthquake.

Fundamentals of political interest: aid between two countries is usually tied to political interest of the two countries. The givers demonstrate political interest in support of the policies of the leaders of the recipient country. (Bodomo 2013) claimed that aid transfer among two countries only takes place when it is in the political interest of both leaders. In similar vein, (Ghani et al. 2005) supports the view that, it aims primarily at creating parallel structure to pick up the responsibilities that could not be performed by the recipient country. In any case, the inbuilt agreement and interest of the leaders could not be over emphasized. The tie might enhance effectiveness in a good policy environment void of corruption. However, in most cases it is a strong tent to shade the poor accountability of the recipient states, given the initial cooperation that led to the aid agreement.

\section{Argument of poor representation of donor's interest}

Many donors, foreign government and international agencies route most of their aid through representative NGOs and domestic government agencies. Only a few, such as Safe the Children, World Vision, Family Health International and others bypass political and government affiliation in discharging their humanitarian interventions. Even then, they are not completely independent of partnership with community based organizations. Aside the few organizations most foreign donors identify representatives in the recipient country who act as the affiliating body or representative that liaise with local implementing organisations. In most cases, information asymmetry between the donor representatives and the actual donor is the main source of inefficiency. In the case of Haiti crisis of 2010, most of the US interventions were routed through representative NGOs. Unfortunately the impact of the intervention has been argued to be minimal. Meanwhile, the reports of the representative agencies have been pretty good. In his review, (Cunningham 2011) explained that;

'.........development programs in Haiti have never lacked financial backing. Nor did they at the time of the January 2010 earthquake, when 80 percent of all aid to Haiti and 90 percent of all US aid was channeled through NGOs and contractors. In 2011, the figure jumped to 99 percent. The decision making procedures, lack of principles, and absence of harmonized rules and norms of the humanitarian aid regime, conspired to prioritise the interest of donors and implementing agencies over those of earthquake-affected populations, rendering the regime ineffective' (Cunningham 2011)

It is unfortunate that donors adopted the report as presented and approved by the donor representatives and implementing agencies, they assumed that evidence of evaluation and monitoring team were strictly adequate to justify the reports. Unfortunately, the implementing chain alongside the donors' representatives is usually not free of inherent project failure. The reality of aid administration is that, it is a big deal to experience a life changing reality of the post project outcome, but it is not a serious deal to produce a perfect document during the implementation and the post project evaluation periods. Corruption is usually a chain work. 
Meanwhile, it should be pointed out that it is not the entire staff in the chain operation that are inefficient, but in most cases, the shady deal of inefficient representatives outshines the bright potentials of the highly principled and discipline staff and monitoring team. In all, donor misrepresentation, information asymmetry and conflicting interest are big problems that contribute to foreign aid inefficiency across the world.

\section{Methods and Presentations}

\section{Conceptual frame of current foreign aid administration}

It is difficult to capture all issues around foreign aid administration in a single article. However, the Fig. 1 is developed to simplify the argument. It is a prototype of the chain of operational settings that limit the effectiveness of foreign aid administration.

Inefficiency in the administrative procedure of foreign aid is a chain operation with feedback effects that are capable of redefining a project outcome positively or negatively. The fundamental problem in the chain process is attributed to the weak monitoring teams and insensitivity of the donor representatives to their oversight function, though in many other cases, the representative joins hands with the weak monitoring team and implementing agencies to under prioritise the aim and objectives of the

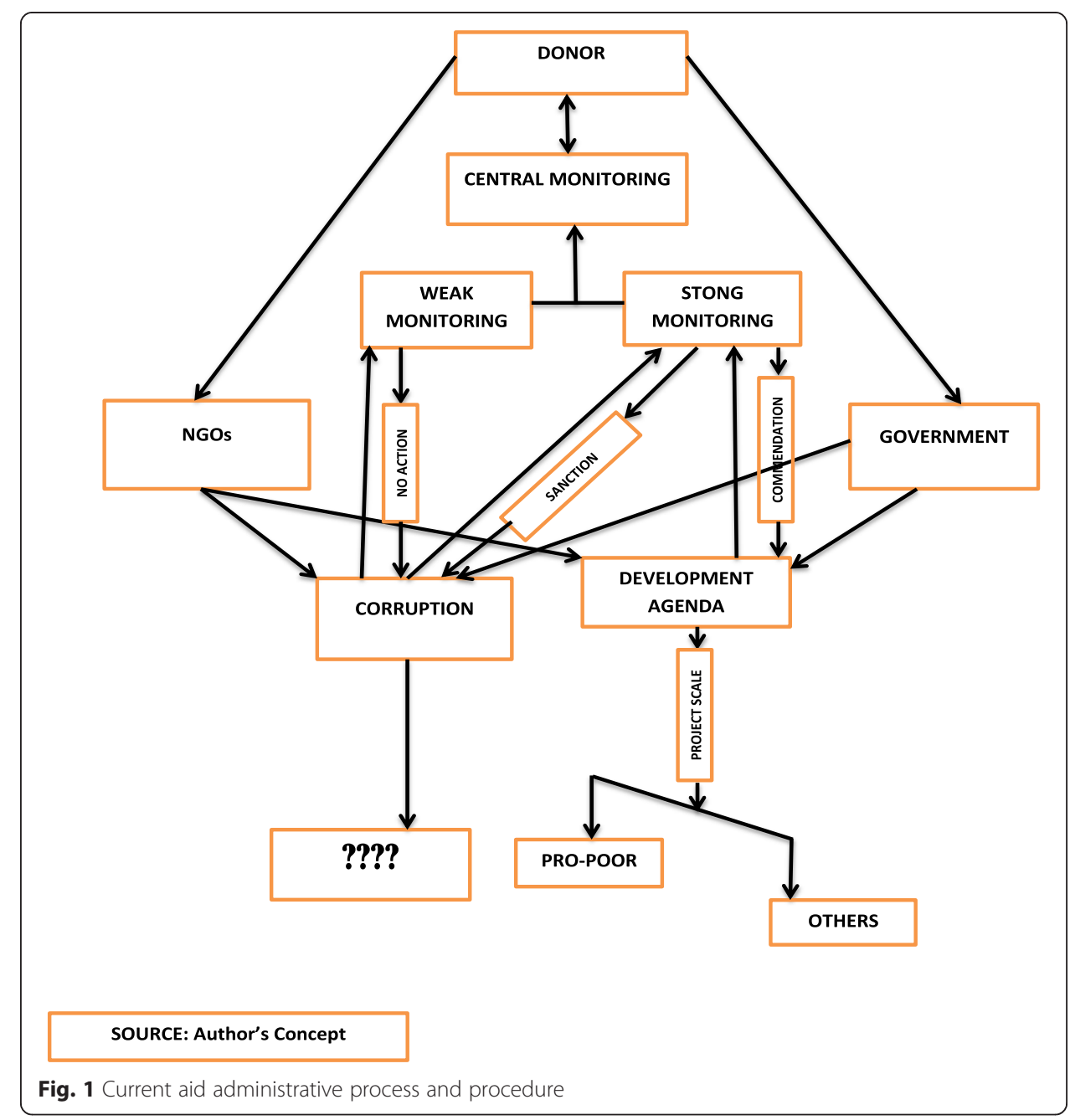


project in favour of their own self-interest. While a strong monitoring team is a guiding soldier to force implementing agencies adhere strictly to project principles and implementation guidelines, its activities are limited to ensuring that project is implemented based on the specifications of donor representative. It has no control on the quality of the project in terms of its pro-poor inclinations or otherwise, which is usually the priority of foreign aid to developing and under developed countries. These limitations play key roles in the poor implementation of Poverty Reduction Strategy Paper (PRSP) of IMF and World Bank in most of the countries (Craig \& Porter 2003).

The weak process could only be corrected through invigoration of the operations of donor, administrative representatives, monitoring and evaluation teams. Though, implementing agencies are critical but the system could be autocorrected if the key members of donor chain system are fully reorientated and the administration and project identification process are reformed, with full attention given to the priority areas of development. A lesson in this regard could be drawn from remittances template.

\section{Foreign aid and remittances: can former learn from latter?}

Remittance is well established in the literature as a major source of foreign exchange in underdeveloped and developing economies. The interest of researchers in studying its impact in recent time is connected to the increase in its volume and the visible impact it makes on grassroots development in the developing economies. Data has indicated that African Diaspora's remittance is not only far exceeding the foreign aid, but also substantially better than foreign aid in terms of administration and impact. The greatest advantage that funds through remittance have over foreign aid is that remittances go directly to the remiters' target which is the welfare of the remitees, (Baldé 2011). The logic is that, it is easier for family members to know the financial situations of their families in the country of origin and remit accordingly.

The differences between aid and remittances are acknowledged, given that the sources and the channel of transmission are different, however, lessons could be drawn from one to the other; the two are foreign exchange and target directly or indirectly human development in the recipient countries. For instance, unlike remittances, foreign aid is not a free gift, some attract marginal interest and some others are attached to stringent conditions which may be suicidal when viewed within the philosophy or the economic reality in the recipient country. In the myriad of conditions and economic stringencies, critics have picked up the arguments that foreign aid is ending up as a neo-colonial tool to influence the socio-economic and socio-political decision making in the recipient countries. These are unlike remittances. Given the background to aid administration, (Cunningham 2011) submit that 'though remittances are used mostly for family consumption while foreign aid is used for public service delivery, remittances go a longer way to improve on the general welfare of the citizens than foreign aid, given the latter's dismal record in funds mismanagement'. This is much informative on the differential impacts of aid and remittances. The size of remittances which is a major discussion in many studies is not the key issue in this article, rather its target and impact. Socio-economic stability at macro level is best driven by micro effect of household stability, as such, any development initiative that fails to strengthen the socio-economic development cannot stand the test of time. 
Remittances also differ from foreign aid in that remitters do not target national development when taking decision on what to send home, instead, they target the immediate household with sole aim to lift farmily members out of poverty and prepare ground for self-sufficiency and sustainability when the remitter returns from diaspora (Orozco 2003; Sander \& Mainbo 2005). However, in the long-run such individual decision at various locations culminate in community development. Remitters never plan for national development at the onset, but being a bottom-up approach, the impact on the national development could not be over-emphasized, (Acosta 2006). In other words, aid aims at national development using community level as driving force, but the top down bottleneck prevents its efficiencies.

The unique administration and management of remittances has led to holistic development in many countries at local and national levels. In a study of Pakistan remittances, it is acknowledged through a Pakistan Economic Survey in 2012 that, rise in remittances to Pakistan has helped to partially offset the negative effects of the oil crisis, reduced unemployment and improve the living standards of recipient households, (Ahmed \& Martinez-Zarzoso 2013). The outcome of the survey made the government to intensify effort on increasingly relying on remittances for its economic development, (Mughal \& Makhlouf 2013). It is argued in a related study that the effectiveness of remittances is particularly felt when Foreign Direct Investment (FDI) and Official Development Assistance (ODA) flow to the country dried up. At a time, the country was not succeeding in attracting new foreign investments due to the fragile state of the economy and the inflow was deteriorating consistently. However remittances as a major source of foreign exchange successfully closed the created developmental gap (Ahmad \& Malik 2009).

Consequently, various studies on the efficacy of administration and management of remittances provoked the conceptual framework of remittances designed in the Fig. 2 as a learning tool for aid administration;

Remitters' primary target is households and resources are distributed on the provisions of basic means of individual empowerment, such as payment for the education of youths and children, sharing of varying amounts for small scale businesses among the members of the family who require financial empowerment, while some amounts are dispensed on the basic households infrastructures in terms of houses and shelters. The shelters might be meant for immediate family use or as a proactive preparation prior to the return of the remitter after the foreign sojourn. In any case, remitters target individual households with little or no concern for the national development.

The immediate impact and motivation of remitters is the life changing reports from the households. However, as the development of various households at different time and space are combines, the nation begins to transform vis-à-vis the impact on community development. Remitters are aware of the news of the transformation at the community and the national economy, but are less sensitive to the fact that they are responsible for the transformation. Thus, they are less excited on the changing atmosphere in the country's socio-economic environment.

\section{Results and the Proposal}

\section{Towards a new approach to foreign aid administration}

The aim of this contribution is to harmonize the current foreign aid administrative and remittances frameworks, in a way to redefine the conceptual administrative procedures 


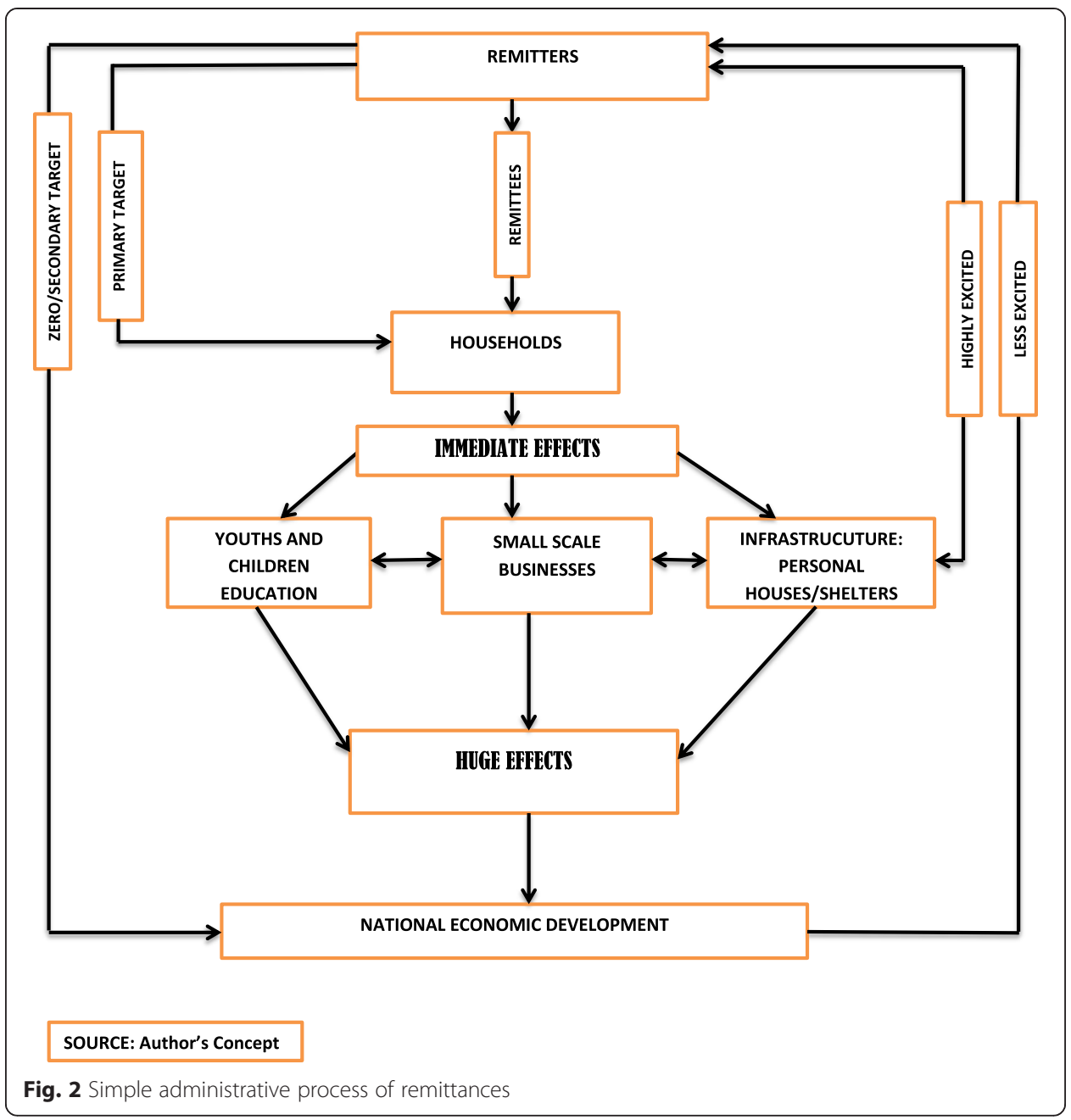

for aid administration and management in the less-developed and developing economies. A proposal for redefinition of roles of key actors in aid administration is therefore presented in Fig. 3. For simplicity, all foreign aid, irrespective of bilateral or multilateral is classified as technical or non-technical aid. Technical aid is defined as all forms of skills and expertise transfer that are void of monetary commitment to administrators. All other developmental aid, including scholarship grants are referred to as non-technical aid.

The key points in the proposal as presented in Fig. 3 are discussed in succession:

\section{Redefining roles of donor organizations}

Most foreign aid donors operating in the developing and underdeveloped countries are western based. Their donations are usually channeled through national government of the recipient countries or prominent NGOs, with few having their standard offices in the country, although some bilateral donors route their donations through embassies or consulates. However, the primary assignment of such organizations is not to monitor the activities of the recipients. While some organizations such as United Nations Development Programme (UNDP), United States Agency for International Development 


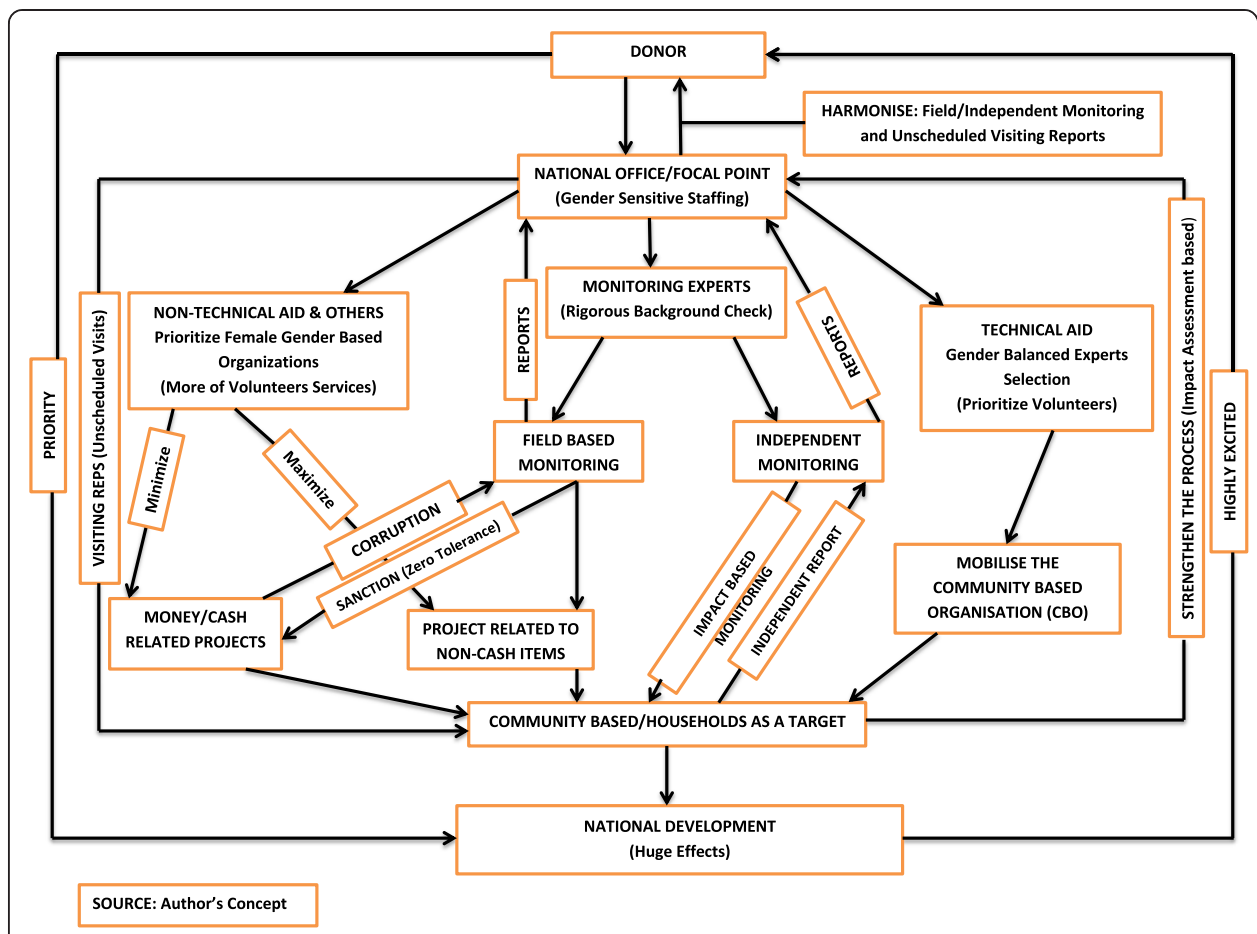

Fig. 3 Proposed aid administrative process and procedures

(USAID), Department for International Development (DFID) etc., are well established in most of the recipient countries, unfortunately, they are far from the community levels where project activities are carried out. The role of those offices are merely to award projects to the country-based NGOs and agencies with the expectation that project reports, monitoring and evaluation proceedings would be adequate to measure the probity of the implementation process. This procedure however appears inappropriate and obsolete, fraught with deep rooted corruption among government agencies and NGOs.

It is proposed that donors should shift from national headquarters based staffing approach to grassroots and community compliance staff engagement. Poverty alleviation is a passion driven activity that requires sacrifice, discipline and commitment to ensure drastic reduction in poverty level, and not a document based satisfaction that is produced after project implementation. Passionate community development workers are better identified through volunteering services as against knowledge based experts who appear extremely fat in the midst of the poor they are supposed to serve.

More so, all donors might not be able to establish standard offices in all the countries of engagement. However, it is very important to identify related donor organizations that would objectively and adequately discharge the oversight function to ensure full realization of the objectives of the project for grassroots impact. If the national NGOs are to be contracted as country representatives of the donor, comprehensive background check would have to be conducted before any purposeful contract is agreed. The donor's desire and readiness to alleviate poverty is critical in redefining the impact of foreign aid in developing countries. 


\section{Gender sensitive staffing across board}

Gender sensitivity has important role to play in pro-poor developmental projects at all levels, from the donor staff members to the grassroots/community level. It is not news that poverty affects women and children more than any other group in a society, especially in less developed and developing economies. When poverty is acute, empowered women provide passionate, better and logical solution than male gender. Any developmental agenda that trivializes the role of women in project implementation at any level would risk the quality of the execution and compromise the realization of the targeted output. Gender mainstreaming is widely campaigned, but less effected. In reality, many donors and their agencies place serious attention on expertise based staffing than gender based approach. While it is true that expertise is critical in project implementation, developmental project needs female inspiration, passion and commitment to change the status quo than a gender biased expertise based project staffing. This is evidenced in the willingness of female to participate in volunteering jobs than male gender.

\section{Prioritizing non-cash donation and technical aid}

Excessive cash release for developmental projects is aggravating the effect of corruption on donor funded projects. Donors or country representatives could rescue the system through the minimization of cash-based projects and donations. Acquisition of required equipments/items and supply of technicians and experts for project implementation would minimize the tendencies of the implementing agencies engaging in corrupt practices. Meanwhile, when technical supports are supplied, the passionate and development sensitive volunteers and experts are better as partners than pure consultants whose motivation is what to get out of the project than what to contribute towards the realization of the underlining aim of the projects.

\section{Multi-level project monitoring}

The roles of monitoring team are critical to the achievement of project objectives, as such; some agencies tactically lure them into the chain of corruption for selfish interest. To alleviate this problem, deep background check on all members of monitoring team at all levels are essential. Field monitoring team should be responsible for day-to-day monitoring activities of the implementing agencies and ensure that they comply strictly to the laid down project objectives. Meanwhile, an independent monitoring team is to be responsible for impact assessment through sampling of opinions among the project target group to ensure adequacy in terms of quantity and quality of project output. For the effectiveness of the process, recruitment of the monitoring team should be undertaken directly from the country office of the donor or their representative.

The independent monitoring teams would be more effective if their identities are not disclosed to the implementing agencies and the field monitoring staff. The third layer of monitoring should be a periodic and unscheduled visit from the donor office to the target community or group for sampled opinion, which would serve as control report when harmonizing the final presentation of field and independent monitoring teams alongside the implementing agencies' report. 


\section{Zero tolerance for corruption}

The concept as presented in Fig. 3 has inbuilt process for checkmating corruption. For instance, prioritizing volunteering activities is a way to identify passionate development workers. So also, mainstreaming of gender balance would reduce the tendencies of corruption than gender insensitive arrangement. The rigorous background check of the monitoring team would minimize the appointment of corrupt monitoring staff. More so, the promotion of community based organization as implementing agencies is an incentive for effectiveness. Mandating the monitoring team to accommodate zero corruption tolerance level in implementation process would caution all parties in the project chain.

\section{Bottom-up approach as against a top-down approach to development project}

The proposed concept is to bring donors closer to the community level instead of multilevel procedures that flows from the national to the local communities. The whole process of top-down approach is usually weakened before the proceedings of the donors intervention gets to the people at the grassroots. In other words, the proposed idea is to ensure that the development target of donors is shifted from national development that are indirectly aimed at the grassroots community to those that are directed at the grassroots development with medium and long term expectation to promote national development. This pro-poor approach is fundamental to the achievement of the poverty alleviation objectives of most foreign aid to the underdeveloped and developing countries.

\section{Conclusion}

Foreign aid is one of the three biggest sources of foreign exchange to developing economies. Its aim is to enhance development process vis-à-vis poverty alleviation and infrastructural development. However, the huge amount injected for the purpose is not producing a commensurate output and impact expected. This has engendered a debate on the efficiency of aid in promoting development. Literatures have highlighted various reasons for the ineffective process which are attributed to the inefficient system, corrupt practices at all levels and information asymmetry among the parties. This article therefore, harmonizes the limitations and juxtaposes them in the mirror of remittances administrative process, and thus, proposes some adjustment to the current foreign aid management and administrative process. Key issues in the proposal includes, a bottom-up approach rather than top-down processes, gender sensitivity in designing the administrative process and in-built control for all parties to exhibit probity in discharging duties as against the current corruption that are prevailing at all levels.

Competing interest

There is no conflict of interest.

Acknowledgement

Adeoba Ojekunle is specially appreciated for his constructive criticism of the first draft and special thanks to anonymous reviewers.

Received: 19 February 2015 Accepted: 29 September 2015

Published online: 16 October 2015 


\section{References}

McMichael P (2011) Development and social change: A global perspective. Pine Forge Press.

Kaplan A (1999) The developing of capacity. Community Development Resource Association, 1-32.

Morrissey O (2002) Aid effectiveness for growth and development. Odi opinions, 2.

Asongu S (2015) Reinventing foreign aid for inclusive and sustainable development: Kuznets, Piketty and the great policy reversal. Journal of Economic Surveys

Sachs J (2006) The end of poverty: economic possibilities for our time. Penguin.

Crawford PW (2004) Aiding aid: a monitoring \& evaluating framework to enhance international aid effectiveness. University of Technology, Sydney

Nunnenkamp P, Öhler H (2011) Aid allocation through various official and private channels: Need, merit, and selfinterest as motives of German donors. World Development 39(3):308-323

Easterly W (2002) How did heavily indebted poor countries become heavily indebted? Reviewing two decades of debt relief. World Development 30(10):1677-1696

Bulow, J, \& Rogoff, K (1991) Is the World Bank a Preferred Creditor. mimeo, Stanford University.

Moyo D (2009) Dead aid: Why aid is not working and how there is a better way for Africa. Macmillan.

De Mesquita BB, Smith A (2007) Foreign aid and policy concessions. Journal of Conflict Resolution 51(2):251-284

Bodomo A (2013) African Diaspora Remittances are Better than Foreign Aid Funds. World Economics 14(4):21-29

Ghani A, Lockhart C, Carnahan M (2005) Closing the sovereignty gap: an approach to state-building. Overseas Development Institute, London

Banerjee AV, He R (2007) Making aid work (pp. 91-97). MIT press, Cambridge

Cunningham $O$ (2011) The Humanitarian Aid Regime in the Republic of NGOs. Journal of Advanced International Studies 4:102-24

Craig D, Porter D (2003) Poverty reduction strategy papers: a new convergence. World development 31(1):53-69

Baldé Y (2011) The Impact of Remittances and Foreign Aid on Savings/Investment in Sub-Saharan Africa. African Development Review 23(2):247-262

Orozco M (2003) Remittances, the rural sector, and policy options in Latin America. In United States Agency for International Development-World Council of Credit Unions conference,"Paving the Way Forward for Rural Finance: An International Conference on Best Practices", Washington, DC (pp. 2-4).

Sander, C, \& Mainbo, S M (2005) Migrant labor remittances in Africa: Reducing obstacles to developmental contributions. World Bank Openknowledge

Acosta P (2006) Labor supply, school attendance, and remittances from international migration: the case of El Salvador. World Bank Open knowledge

Ahmed, J, \& Martinez-Zarzoso, I (2013) Blessing or curse: The stabilizing role of remittances, foreign aid and FDI to Pakistan (No. 153). Discussion Papers, Center for European Governance and Economic Development Research.

Mughal M, Makhlouf F (2013) Labour effects of foreign and domestic remittances-evidence from Pakistan. International Review of Applied Economics 27(6):798-821

Ahmad E, Malik A (2009) Financial Sector Development and Economic Growth: An Empirical Analysis of Developing Countries. Journal of Economic Cooperation and Development 30(1):17-40

\section{Submit your manuscript to a SpringerOpen ${ }^{\circ}$ journal and benefit from:}

- Convenient online submission

Rigorous peer review

- Immediate publication on acceptance

- Open access: articles freely available online

- High visibility within the field

- Retaining the copyright to your article 